\title{
Review
}

\section{The biosociology of pancreatic B cells*}

\author{
D. Pipeleers \\ Department of Metabolism and Endocrinology, Vrije Universiteit Brussel, Brussels, Belgium
}

For almost a century, diabetes research has focused on the endocrine pancreas and its secretory products. This particular orientation started in 1889, after von Mering and Minkowski had noted the development of diabetes in pancreatectomized dogs [1]. Four years later, Minkowski demonstrated that the antidiabetic activity of the pancreatic organ was not the result of its exocrine secretion [2]. Within the same year, the islets of Langerhans were held responsible for an internal secretion which regulated glucose homeostasis [3, 4]. It then took seven decades before the islet tissue was submitted to functional analysis. The development of techniques for the isolation of pancreatic islets [5-7] finally created opportunities to study the insulin releasing B cells in vitro. Reviews by previous Minkowski lecturers have outlined how this in vitro work has elucidated major events in the process of insulin biosynthesis and release [8-14]. The recognition of a cellular heterogeneity in mammalian islets raised, however, the question to which extent the functions of the pancreatic B cells depend on a particular organisation of these cells within their own society or within other (neuro)endocrine systems (Fig.1). In order to investigate this issue, we developed methods for the purification of islet cells and for their in vitro analysis. It was the purpose to first examine the functional characteristics of $B$ cells which had been isolated from their natural environment, and then to reconstitute, step by step, their in situ configuration and functional activities.

\section{The purification of islet cells}

Techniques for the purification of islet cells have been developed in the rat, where standardised methods exist for the reproducible isolation of pancreatic islets [7, 15] and for their dissociation into single and viable cells $[15,16]$. They take advantage of the differences which

* The Minkowski Award Lecture at the 21st Meeting of the European Association for the Study of Diabetes, Rome, September 1986

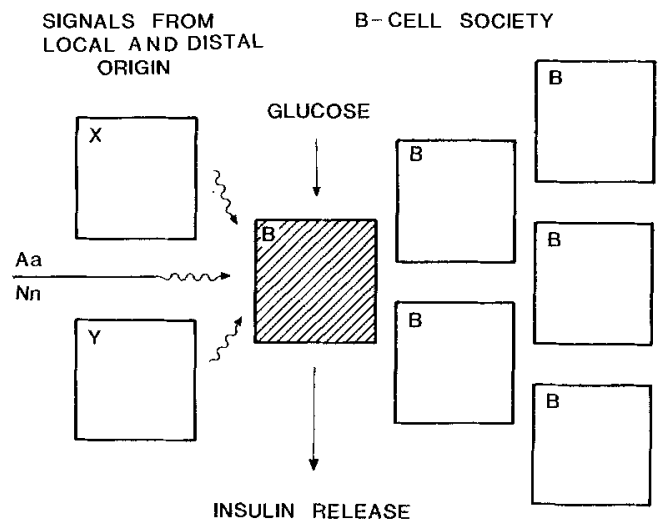

Fig. 1. Hypothetical model for the functional organisation of pancreatic B cells. The ability of glucose to stimulate insulin release from an individual B cell may depend (1) on the relationship of this cell with other members of the B-cell society and (2) on its interactions with signals which originate, locally or distally, from other cell types

Table 1. Methods for the purification of islet cells

\begin{tabular}{ll}
\hline Parameter & Technique \\
\hline $\begin{array}{l}\text { 1. Sedimentation velocity } \\
\text { 2. Cell density }\end{array}$ & $\begin{array}{l}\text { Centrifugal elutriation } \\
\text { Isopycnic gradient centrifuga- } \\
\text { tion }\end{array}$ \\
$\begin{array}{l}\text { 3. Surface binding to B-cell spe- } \\
\text { cific antibodies }\end{array}$ & $\begin{array}{l}\text { Fluorescence - activated cell } \\
\text { sorting }\end{array}$ \\
$\begin{array}{l}\text { 4. Cellular endogenous fluores- } \\
\text { cence }\end{array}$ & $\begin{array}{l}\text { Autofluorescence-activated cell } \\
\text { sorting }\end{array}$ \\
\hline
\end{tabular}

have been identified in the chemical, physical and biological properties of the various islet cell types (Table 1).

Cell size was the first detected parameter for the separation of islet cells [17]. Both in volumetric and surface analysis, insulin-containing $B$ cells were found to be two- to three-fold larger than the other islet cell types (Fig. 2, [16]). According to Stokes' law, islet B cells should thus exhibit a higher sedimentation veloci- 


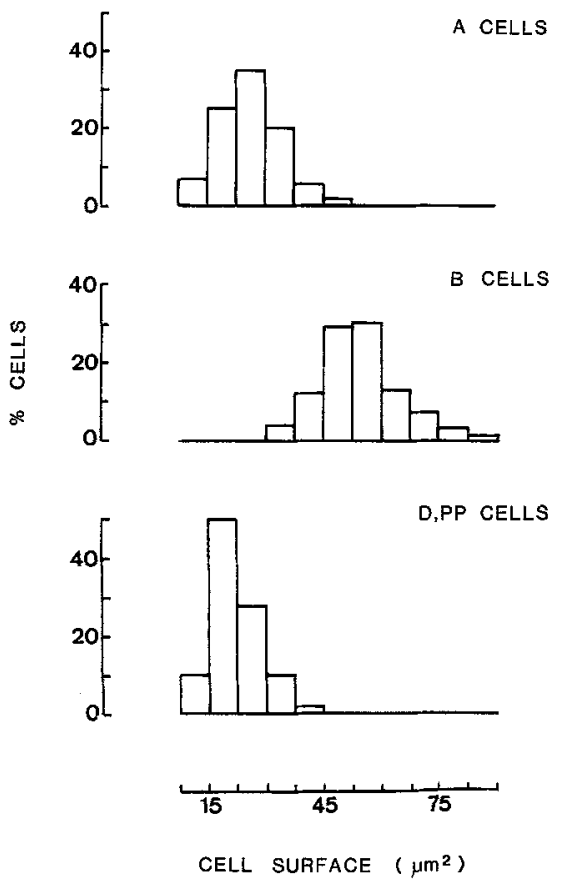

Fig. 2. Size distribution of rat pancreatic islet cells. Cell surfaces were measured by semi-automatic analysis of dissociated islet cells fixed in glutaraldehyde. Reprinted with permission from [16]

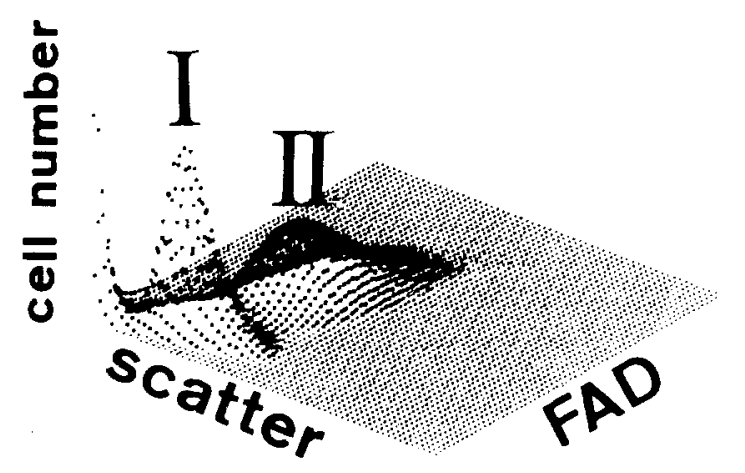

Fig.3. Analysis of rat islet cells during autofluorescence-activated cell sorting. The tridimensional display plots the cells according to their light scatter activity and endogenous FAD fluorescence. The two distinct populations correspond to single non-B cells (I) and single $B$ cells (II)

ty than islet non-B cells. Centrifugal elutriation, which separates cells according to their sedimentation velocity [18-20], distributed the islet cells over a first single cell fraction enriched in islet non-B cells, a second single cell fraction composed of more than 90 percent $B$ cells and a third fraction of mostly structurally coupled cells [16]. The knowledge that islet B cells were separable on the basis of their larger size $[16,17]$ led to attempts to purify islet cells by flow cytometry, with the cellular light scatter activity as separation parameter. In our experience, light scatter alone discriminates poorly between islet $B$ and non- $B$ cells and can therefore not be adequately used for their isolation [21, 22]. Other laboratories also were unsuccessful in purifying islet non-B cells by light scatter flow cytometry, but re- ported on the ability of this technique to isolate islet $\mathrm{B}$ cells [23-26], albeit at a lower cell yield and a lower degree of purification than with other methods $[15,16$, 21].

Differences in cell density can be employed to purify glucagon-containing A cells from islet cell preparations which are already enriched in islet non-B cells [16]. Isopycnic gradient centrifugation of elutriated islet non-B cells yields preparations with more than $90 \%$ A cells between densities 1.067 and $1.07 \mathrm{~g} / \mathrm{ml}$, but the final cell yield is less than $20 \%$ [16].

The availability of isolated islet $B$ and non- $B$ cells led to the recognition of circulating islet cell surface antibodies (ICSA) which bind to the insulin-containing cells but not to the other islet cell types [27]. These IgG antibodies were primarily detected in recently diagnosed Type 1 (insulin-dependent) diabetic patients younger than 30 years of age [27], the population wherein ICSA were first described [28]. They have been used to fluorescently label the islet $B$ cells so that they become separable by fluorescence-activated cell sorting [27]. Monoclonal antibodies binding selectively to $\mathrm{B}$ cells have also been employed for this purpose $[29,30]$. Sorting of B cells labeled with cell selective antibodies is, however, hindered by two disadvantages: first, the inability to eliminate islet non-B cells which are attached to fluorescent B cells and which therefore contaminate the isolated preparation, and second, the persistence of surface antibodies on the isolated cells which limits further cell biological experimentation.

The endogenous fluorescence of the cells was found to be a most useful parameter for the purification of islet cells $[15,21]$. In addition to yielding highly purified islet cell suspensions, autofluorescence-activated cell sorting offers the advantage of preparing cells free of exogenous ligand. It also provides a method to distribute the cells according to their functional activities $[31,32]$. The technique takes advantage of the ubiquitous presence of the autofluorescent flavin and pyridine nucleotides [33, 34]. Islets represent a rich source of both constituents and, more importantly, undergo rapid glucose-induced variations in the nucleotides' fluorescence intensities [35-37]. At $2.8 \mathrm{mmol} / 1$ glucose, the histogram of the cellular flavin-adenine dinucleotide (FAD)-autofluorescence intensity contains two distinct peaks when plotted against the light scatter activity of the cells (Fig. 3, [15, 21]). The cell population with low $\mathrm{FAD}$ values consists of more than $95 \%$ single non-B cells, while the cells with higher FAD content correspond to more than $95 \%$ single B cells $[15,21]$. When the isolated non-B cells are re-analysed at $20 \mathrm{mmol} / 1$ glucose, most cells maintain the low nicotinamide adenine dinucleotide (NAD)(P)H levels that are recorded at $2.8 \mathrm{mmol} / 1$ glucose, and only 10 to $15 \%$ increases their $\mathrm{NAD}(\mathrm{P}) \mathrm{H}$ fluorescence intensity two- to four-fold. Sorting of the population with unchanged $\mathrm{NAD}(\mathrm{P}) \mathrm{H}$ content yields virtually pure A cells [15]. 

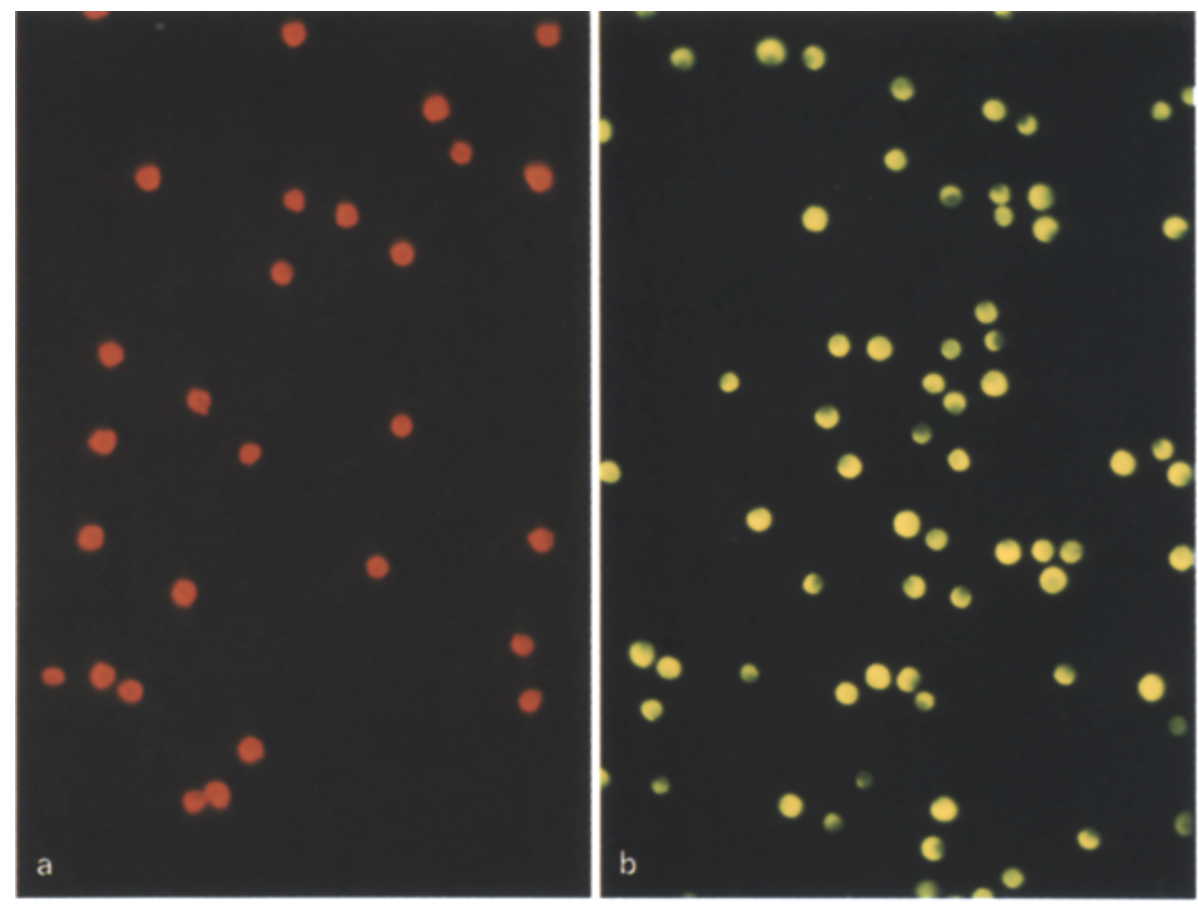

Fig.4a and b. Purified A- (a) and B- (b) cell suspensions after immunostaining for glucagon (a 182x) and insulin (b 126x)

Table 2. Selection of technique for the purification 'of islet cells

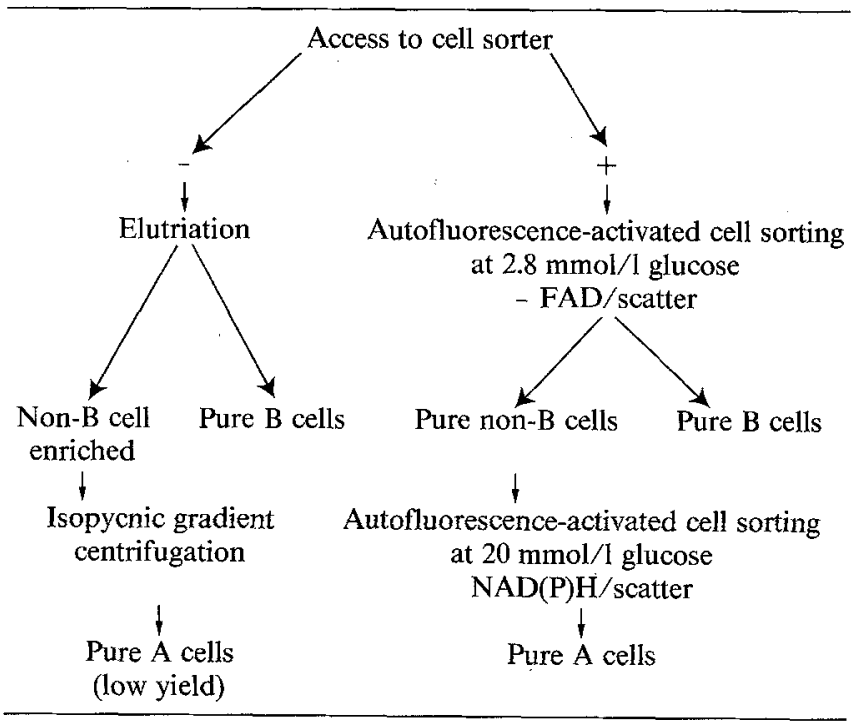

Table 3. Characteristics of purified islet cells

\begin{tabular}{|c|c|c|c|}
\hline & & A cell & B cell \\
\hline Size & $\begin{array}{l}\mu \mathrm{m}^{3} \\
\mu \varnothing\end{array}$ & $\begin{array}{c}250-550 \\
8-11\end{array}$ & $\begin{array}{c}700-1300 \\
11-14\end{array}$ \\
\hline Water space & fl & 200 & 800 \\
\hline $\begin{array}{l}\text { Glucose oxidation } \\
\mathrm{Km} \\
\mathrm{V}_{\max }\end{array}$ & $\begin{array}{l}\mathrm{mmol} / \mathrm{l} \\
\mathrm{fmol} \mathrm{CO} \\
\mathrm{CO}_{2} / \mathrm{h}\end{array}$ & $\begin{array}{l}20 \\
30\end{array}$ & $\begin{array}{r}8 \\
85\end{array}$ \\
\hline Hormone content & $\begin{array}{l}\text { pg glucagon } \\
\text { pg insulin }\end{array}$ & $\begin{array}{l}10 \\
-\end{array}$ & 50 \\
\hline $\begin{array}{l}\text { Number of } \\
\text { Cells per average } \\
\text { isolated islet }\end{array}$ & 570 & 1300 & \\
\hline $\begin{array}{l}\text { Cells per adult } \\
\text { pancreas }\end{array}$ & 400,000 & 1,200000 & \\
\hline $\begin{array}{l}\% \text { Yield in pure } \\
\text { preparation }\end{array}$ & 15 & 25 & \\
\hline
\end{tabular}

Data are taken from $[15,16$ and 38$]$ and express values per cell
At present, the selection of a technique for islet cell purification depends on the availability of a cell sorter (Table 2). Most of the work discussed in this review has been conducted on islet cells purified by autofluorescence-activated cell sorting. The quality control data have been outlined in previous publications $[15,21,22$, 38 . The purity of the A- and B-cell preparations was demonstrated by immunostaining the cells for glucagon and insulin (Fig.4) and was confirmed by cell typing in electron micrographs (Fig.5). The purified cells were well granulated and exhibited an intact ultrastructure of their membranes and organelles (Fig. 5); in scanning micrographs, A cells were characterized by a smooth surface and B cells by multiple short microvillous extensions (Fig.5). The structural integrity of the cells was also demonstrated by their survival in culture [15]. The purity and viability of the isolated cell preparations allowed us to fill in a number of basal characteristics on the passports of rat islet $A$ and $B$ cells (Table 3). 

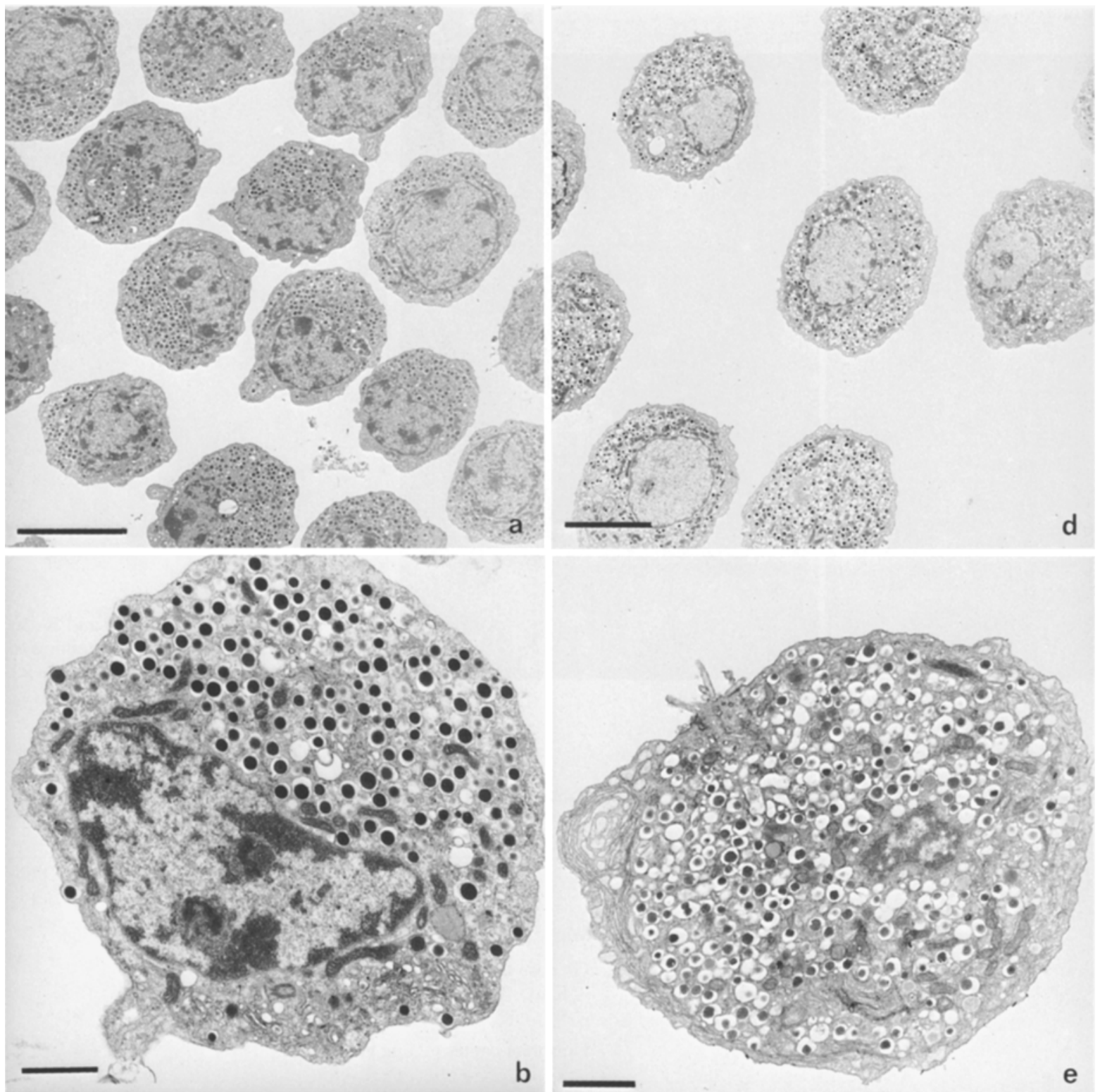

a
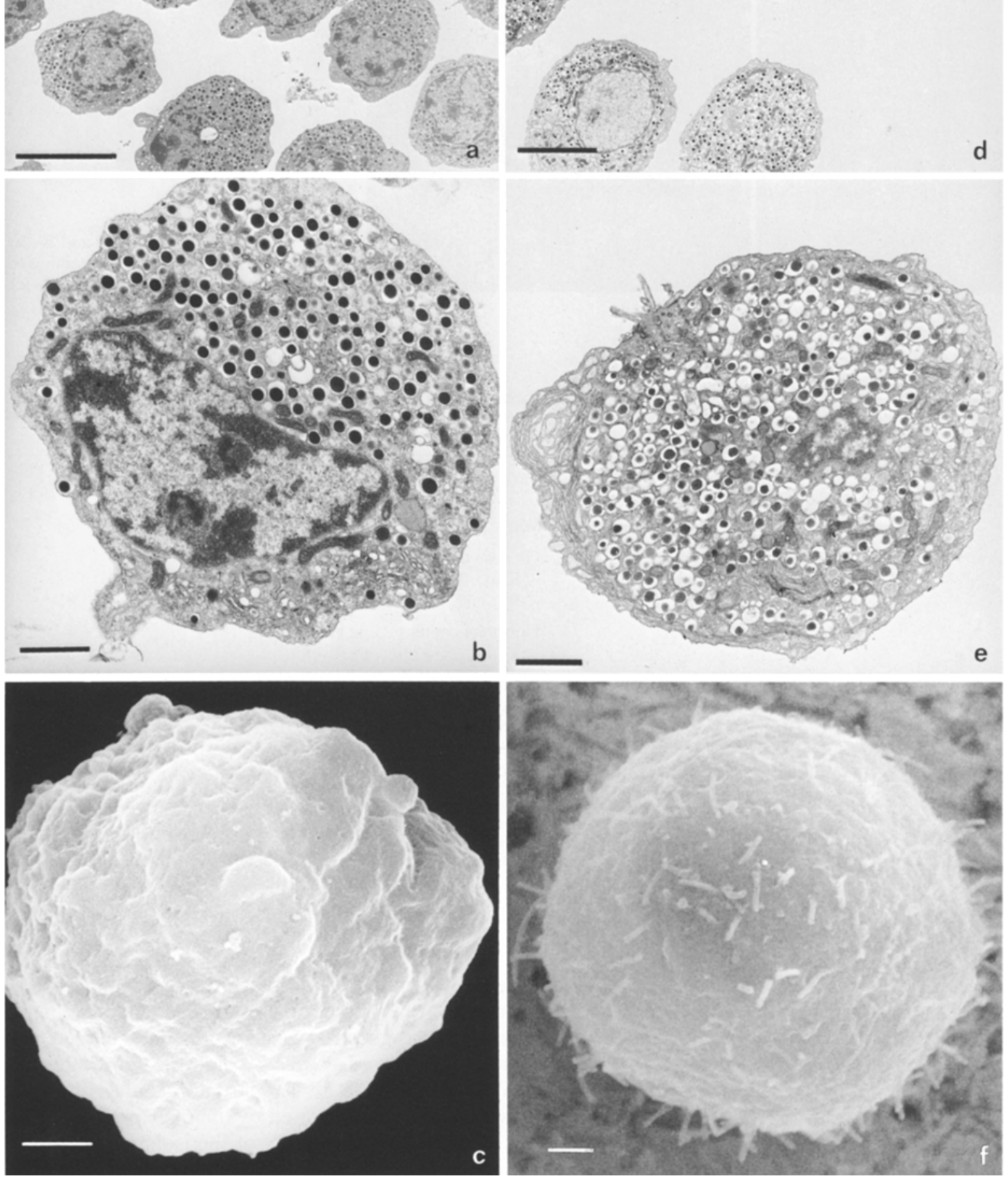

Fig.5a-f. Electron micrographs of purified A (a-c) and B (d-f) cell preparations. The purity of both fractions is illustrated at low magnification: more than $95 \%$ A cells in a ( $\times 1130)$; more than $95 \%$ B cells in d ( $\times 940)$. At higher magnification the well-preserved ultrastructure and granulation are noted in both A cells $(b \times 3850)$ and B cells $(e \times 2540)$. In scanning micrographs, pancreatic A cells are characterized by a smooth surface $(\mathbf{c} \times 3850)$ while the pancreatic B-cell surface contains multiple microvilli (f $\times 2540)$. Bar, $10 \mu \mathrm{m}$ in a and d, and $2 \mu \mathrm{m}$ in b, c, e and f. Reprinted with permission from [15] 

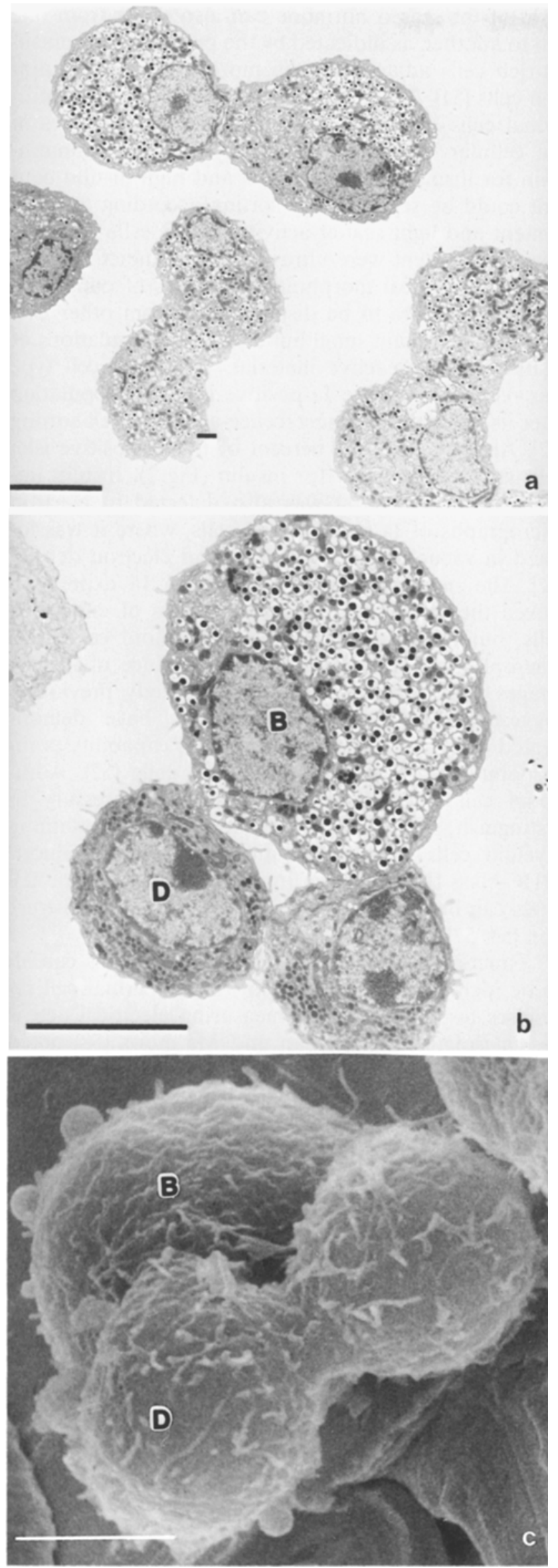

Table 4. The biosociology of pancreatic B cells

\begin{tabular}{ll}
\hline Sociologic organisation & Biological impact \\
\hline $\begin{array}{l}\text { I. Coexistence of functionally di- } \\
\text { verse subpopulations }\end{array}$ & Complementarity in functions \\
$\begin{array}{l}\text { 1. Topography } \\
\text { 2. Hormone content }\end{array}$ & \\
$\begin{array}{l}\text { 3. Responsiveness to glucose } \\
\text { 4. Replicative activity }\end{array}$ & \\
$\begin{array}{ll}\text { II. Aggregated state of the cells } & \text { Potentiation of cell response } \\
\text { III. Synergistic interaction with en- } & \text { Integration and coordination } \\
& \text { vironmental signals }\end{array}$ & in glucose homeostasis \\
\hline
\end{tabular}

\section{Sociologic organisation of pancreatic B cells}

Functional analysis of purified islet cells indicated that adult pancreatic B cells are sociologically organised at three different levels. A first level is expressed in the coexistence of functionally diverse subpopulations, a second level is associated to the aggregated state of the cells and a third level is achieved by the synergistic interactions of the B cells with their environmental signals (Table 4).

\section{Coexistence of functionally diverse B-cell subpopulations}

Evidence for the coexistence of functionally diverse Bcell subpopulations can be derived from the differences in topography of the insulin-containing cells within the endocrine pancreas. In the rat, a proportion of $B$ cells are juxtaposed to the peripheral layer of islet non-B cells; the remaining $B$ cells form a central mass of homogenous composition [39-42]. The peripherally located B cells can be structurally and functionally coupled to islet non-B cells [43-45], and exhibit, in addition, a larger gap junctional area than $B$ cells in the center of the islet [46]. It is now technically feasible to isolate structurally coupled B cells from rat islet tissue $[15,16]$ and to examine the kinetics and regulation of their formation [47]. Glucose and cyclic AMP rapidly increase the number of structurally coupled B cells in the presence of extracellular calcium [47]. These conditions also regulate the number and configuration of the gap junctional units between the coupled cells [48, 49]. It will be discussed later how variations in the degree of B-cell aggregation relate to the functional activities of the cells.

Of the coupled B cells that were isolated from the dissociated islet cell suspension, 5 to 10 percent were

Fig. 6a-c. Electron micrographs of the isolated coupled islet cell fraction. More than $90 \%$ of the cells correspond to B cells, many of which are structurally coupled $(\mathbf{a} \times 950)$. Almost all non-B cells are identified as D cells, which are often coupled to each other or to B cells $(b \times 1700)$. In scanning micrographs, the $D$ cells are recognised by their smaller size and their long microvilli $(\mathbf{c} \times 1700)$. Bar, $10 \mu \mathrm{m}$. Reprinted with permission from [15] 


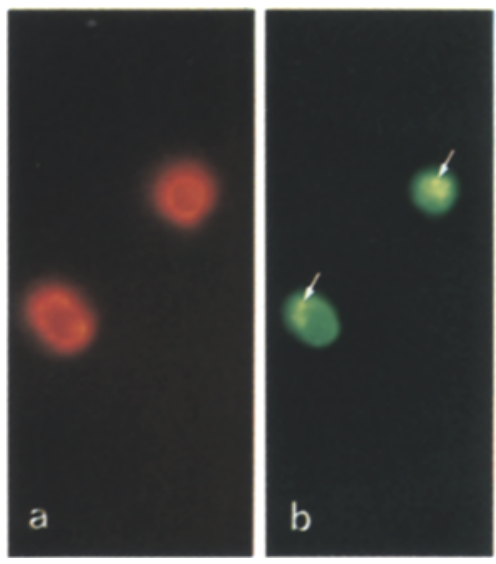

Fig. $7 \mathbf{a}$ and $\mathbf{b}$. Double immunofluorescent reaction of la-positive islet cells for (a) membranous Ia-antigens and (b) cytoplasmic insulin. Approximately $1 \%$ of dissociated islet cells present surface Ia-antigens and can be isolated on this basis. More than $50 \%$ of the isolated cells with rhodamine labeled surface antibodies (a) exhibit a positive cytoplasmic staining for insulin (b arrows) $(\times 600)$ [52]

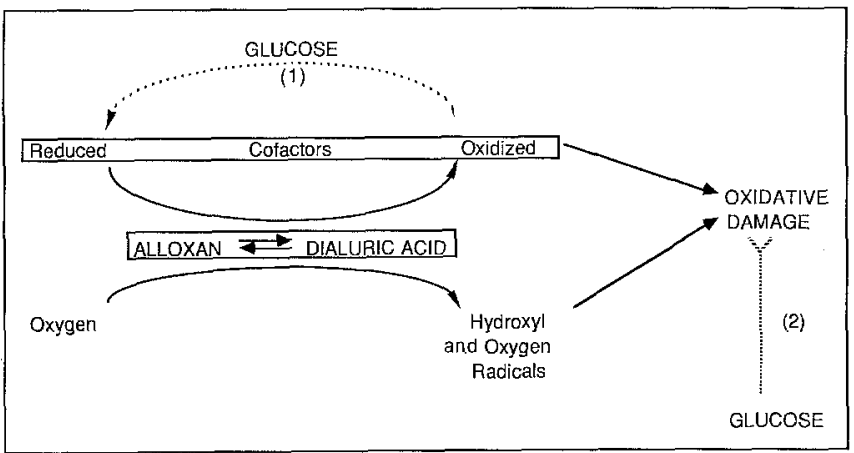

Fig. 8. Diversity in B-cell responsiveness to glucose: implications for cytotoxic effects of alloxan. Pancreatic B cells differ in their metabolic responsiveness to glucose. Cells in which glucose fails to generate reducing equivalents are markedly more sensitive to oxidative damage by alloxan than cells with a high generation rate. Glucose can prevent the cytotoxic effects of alloxan by increasing the level of reduced cofactors prior to or during exposure of the glucosesensitive cells to the oxidative agent [1]. The sugar can also counteract irreversible cell injuries in glucose-sensitive cells that are already exposed to oxidative damage [2]

attached to islet non-B cells, which were almost all identified as somatostatin-containing D cells (Fig.6, $[16,50])$. These heterologous cell formations correspond to the more peripherally located B cells which probably represent a functionally distinct subpopulation, not in the least as a result of their attachment to somatostatin-containing cells. We have, for example, consistently noticed that B cells coupled to D cells were more densely granulated than B cells in homologous cell couples (P.In't Veld and D. Pipeleers, unpublished observations).

An uneven cellular hormone content represents a second sign of heterogeneity in the B-cell population. Differences in the degree of B-cell granulation have been often described by histologists who examined pancreatic sections in aldehyde fuchsin stain [40]. The form of the stored hormone can also differ from one cell to another, as indicated by the presence of proinsulin-rich cells adjacent to the more numerous insulinrich cells [51]. The variation in insulin content of individual cells was also evident from the differences in the cellular fluorescence intensity after an immunostain for insulin. Cells with low and high insulin content could be separated by sorting according to FAD content and light scatter activity. The B cells with low hormone content were ultrastructurally intact and displayed the typical morphologic features of pancreatic B cells. They are to be distinguished from other islet cells which contain small but distinct accumulations of insulin-immunoreactive material. The latter cell type was recognised in the Ia-positive islet cell population after its isolation by fluorescence-activated cell sorting [52]. Approximately 50 percent of the Ia-positive islet cells stained positively for insulin (Fig.7). Insulin immunoreactive material was also detected in electron micrographs of Ia-positive islet cells, where it was located in vacuoles of varying size and electron density [52]. The insulin-containing cells with Ia expression lacked the ultrastructural characteristics of endocrine cells, but rather corresponded to myeloid cells with macrophagic properties [52]. The existence of macrophages in normal islet tissue was already previously suggested [53-55]. Our observations have demonstrated that these cells may exhibit the capability to incorporate fragments of damaged B cells [52]. Additional cell markers may thus become necessary to distinguish, in pancreatic sections, insulin-containing myeloid cells from pancreatic B cells with induced MHC-class II expression, in particular since both cell types can be associated to processes of B-cell destruction $[56,57]$.

Functionally, diverse B-cell subpopulations can also be identified on the basis of the individual cell responses to glucose. While measuring electrical activities in isolated islets, Dean and Matthews [58] noted differences in the glucose-induced effects per cell and postulated that B cells may vary in their individual glucose sensitivity. The availability of pure and single Bcell suspensions led us to measure directly the individual B-cell responses to glucose. The technique of autofluorescence-activated cell sorting was used to determine the metabolic redox state of the cells at varying glucose concentrations [31]. A stepwise increase in extracellular glucose levels resulted in a stepwise increase in the number of $B$ cells with an elevated NAD(P)H and a reduced FAD fluorescence intensity. At $20 \mathrm{mmol} / 1$ glucose, 80 to $90 \%$ of the B cells exhibited two- to four-fold higher NAD(P)H fluorescence intensities than at $2.8 \mathrm{mmol} / 1$ glucose [31]. The 10 to $20 \%$ cells with unaltered NAD(P)H content at high glucose levels appeared ultrastructurally intact and were able to permanently correct the fasting plasma glucose levels when isografted in streptozotocin-diabetic rats. The subpopulation of glucose-unresponsive cells was, how- 
ever, markedly more susceptible to oxidative damage than the glucose-responsive cells. Furthermore, only the glucose-responsive cells were found to benefit from the protective effect of the sugar against alloxan-induced damage [59]. These results can be explained by the opposite effects of glucose and alloxan upon the cellular redox state and, hence, upon cell survival [59, 60]. Besides its ability to prevent a drop in cellular $\mathrm{NAD}(\mathrm{P}) \mathrm{H}$ following alloxan exposure, glucose is also capable of counteracting the cell-destructive consequences of a cytotoxic interaction with the $B$ cells (Fig. 8, [59]). In combination with nicotinamide, glucose enhances the defense reactions in cells which have been exposed to alloxan, streptozotocin, hydroperoxide or B-cell surface antibodies plus complement [59]. The B-cell toxicity of diabetogenic conditions seems thus dependent on the sensitivity as well as on the defensive capability of the target cells. As both parameters will be determined by the glucose sensitivity of the cells, it becomes evident that the diabetogenicity of certain environmental conditions can vary with the relative proportion of glucose-unresponsive cells and with the metabolic conditioning of the glucose-responsive ones. It seems therefore conceivable that metabolic derangements in the B-cell population can predispose to, or accelerate cell-destructive processes of various origin.

A fourth basis for heterogeneity within the pancreatic B-cell population is found in the replicative acitivity of the cells. In the adult islet, only $3 \%$ of the cells have maintained the ability to form new B cells [61]. With the aim of identifying this functionally distinct subpopulation, we tested whether islet cells could be separated according to their DNA content. The cells were labeled with bisbenzimidine (Hoechst 33342, Hoechst AG Frankfurt, FRG), a vital compound which fluoresces when bound to cellular DNA [62, 63], and is then distributed by fluorescence-activated sorting. The technique resulted in the isolation of single B cells with one swollen or with two nuclei; the preparation also contained few structurally coupled cells (Fig.9). Studies are in progress to further characterise the B cells with higher DNA content.

The ability to isolate $B$ cells according to functional properties led us to conceive the pancreatic B-cell population as a society which is composed of functionally diverse subpopulations. As a result of this sociologic organisation, the pancreatic B cells may benefit in situ from a complementarity in functions, each being subject to a specific regulation at the subpopulation level. It can, in this light, be expected that each subpopulation contributes for a variable extent to the hormonal control of glucose homeostasis.

\section{Aggregated state of the cells}

The aggregated state of pancreatic $B$ cells represents a second level of sociologic organisation. Its possible

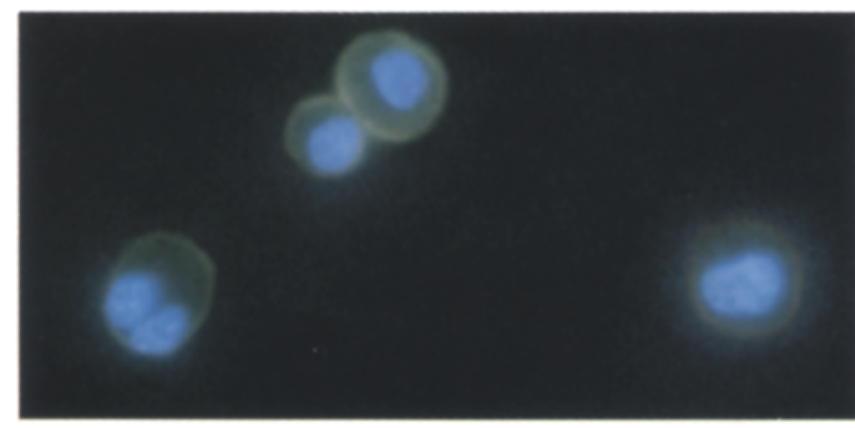

Fig.9. Immunostaining for insulin in islet cells isolated on the basis of a DNA-related fluorescence intensity which is more than $50 \%$ higher than in the large majority of islet cells. The fluorescence originates from binding of bisbenzimidine (Hoechst 33342) to cellular DNA. The isolated cell preparation contains single cells with one swollen nucleus or with two nuclei; few structurally coupled B cells were also noted. Most cells stained weakly positive in the fluorescein reaction for insulin $(\times 640)$

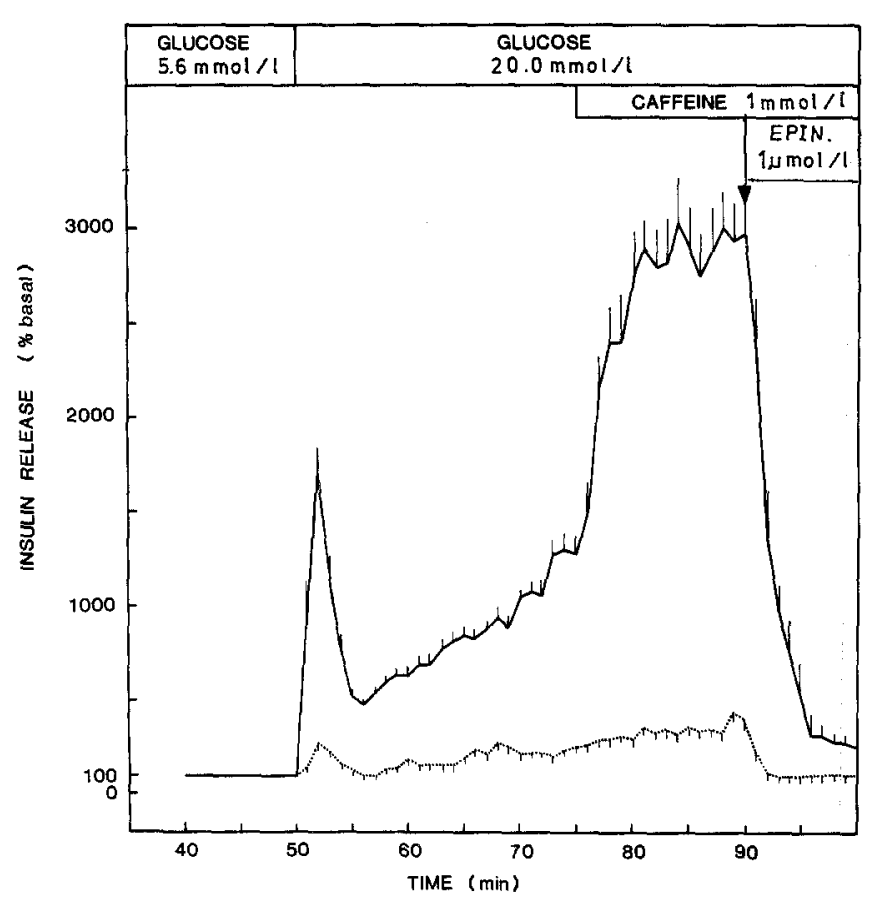

Fig. 10. Insulin release from intact islets (solid line) and from single purified B cells (dotted line) perifused at 5.6 and $20 \mathrm{mmol} / \mathrm{I}$ glucose. Glucose released 30-fold more insulin from B cells lodged within intact islets than from single purified B cells. Reprinted with permission from [66]

biologic impact appeared from the fact that single B cells release markedly less insulin in response to glucose than B cells lodged in intact islets (Fig. 10, [64]). It was more directly illustrated by comparing hormone release from single $B$ cells with that from structurally coupled B cells which were either isolated as such from islet cell preparations (Fig.11, [64]) or which had been reaggregated from single B cells (Fig. 11, [47, 65]). In both experimental designs, glucose-induced insulin release was several-fold higher in coupled B-cell preparations than in single ones. A similar phenomenon 

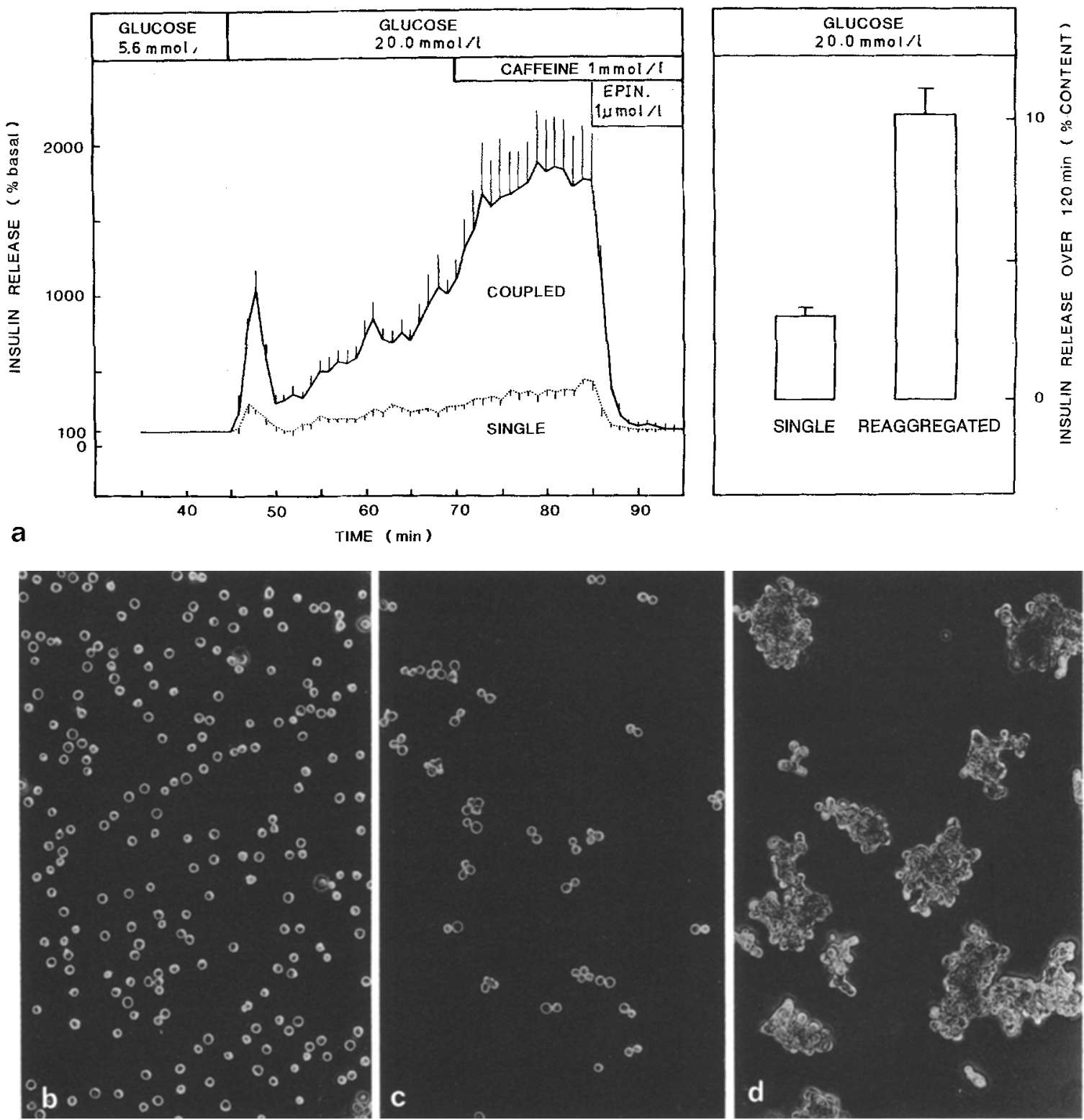

Fig. 11. Glucose-induced insulin release from purified B cells under different states of cell aggregation. The left panel illustrates hormone release from perifused preparations of single $B$ cells (shown in phase contrast in $\mathbf{a} \times 80$ ), and of $B$ cells isolated as structurally coupled units from the dissociated islet cell suspension $(\mathbf{b} \times 80)$. The right panel compares total insulin release over 120 min during a static incubation of single $\mathrm{B}$ cells with that of reaggregated $B$ cells (shown in phase contrast in c, $\times 85$ ). Reprinted with permission from [66 and 67]

was also discerned in unpurified islet cell suspensions that were tested in dissociated and aggregated conditions [66-68].

The higher insulin releasing action of glucose in structurally coupled B cells could not be attributed to an increased rate of signal production as judged by the rate of glucose transport and oxidation [38] or of cyclic AMP formation [69]. It is, however, conceivable that the aggregated state of the cells confers an intracellular organisation which facilitates the process of hormone transport and release [70]. Structurally coupled cells may also coordinate - and hence amplify - their secretory activity via an intercytoplasmic exchange of signal molecules [71, 72], but direct evidence for such regulatory mechanism is still lacking. Gap junctions have been recognised between reaggregated $B$ cells [65], with a number of junctional units which increases with the cellular cyclic AMP levels [48] and a configuration which rapidly varies with the extracellular glucose and calcium concentrations [49]. That the cellular structures implicated in the communication between B cells are regulated by calcium, glucose and cyclic AMP certainly strengthens the hypothesis that intercellular interactions between adjacent B cells may play a role in the potentiation of the individual cell responses (Table 4). Further studies on purified B cells can substantiate the molecular and structural basis of this mechanism. 


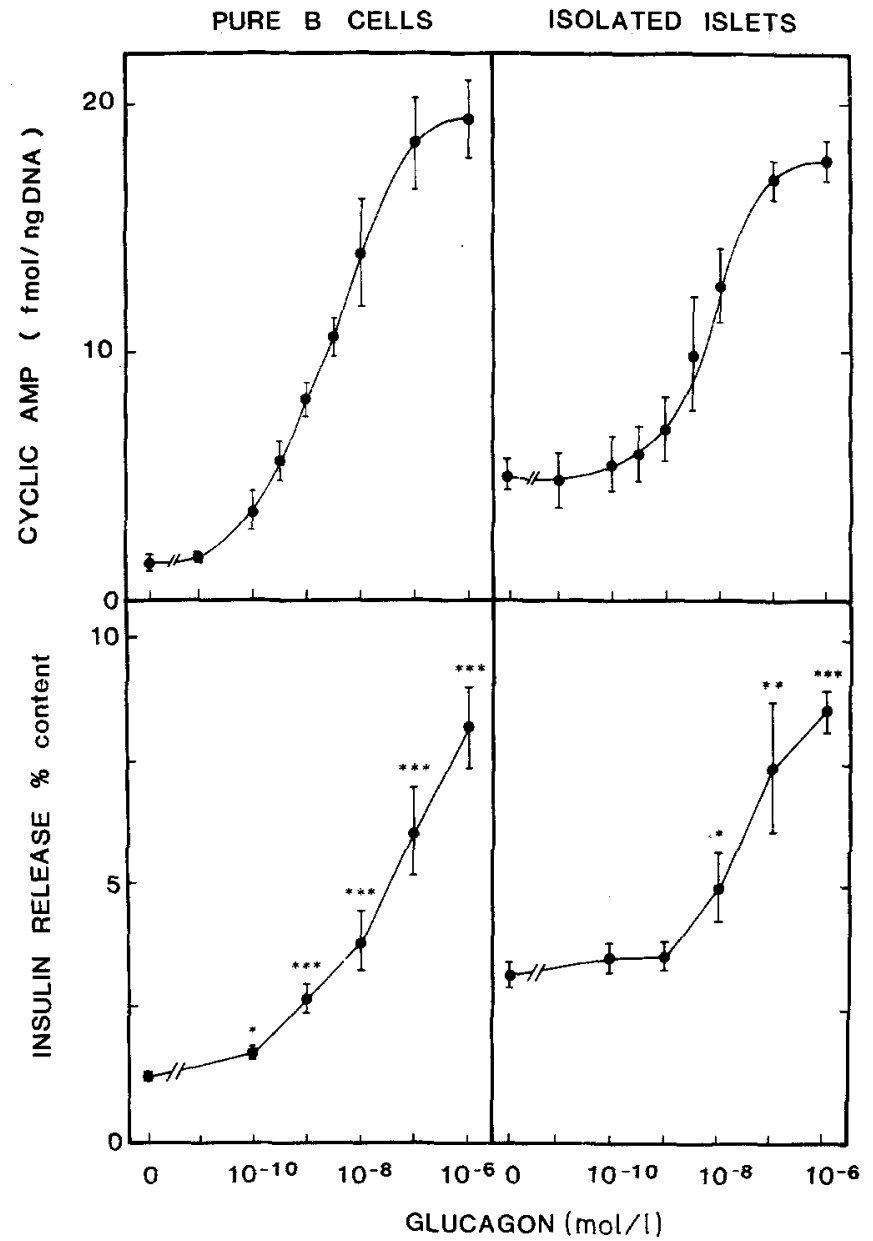

Fig. 12. Parallelism between cyclic AMP formation and glucose-induced insulin release in pancreatic B cells. In the absence of added hormones, both functions proceed at a 3- to 4-fold lower rate in pure $B$ cells than in isolated islets. Addition of glucagon stimulates the two parameters in both B-cell preparations, but pure B cells are 100 -fold more sensitive to the exogenous hormone. In the presence of $5.10^{-9} \mathrm{mmol} / 1$ exogenous glucagon, pure $B$ cells and isolated islets exhibit comparable rates of cyclic AMP formation and glucoseinduced insulin release

\section{Synergistic interaction with environmental signals}

A third level of sociologic organisation was recognised in the interactions of pancreatic B cells with environmental signals

That the secretory function of B cells may be influenced by products from surrounding islet non-B cells was already suggested in the sixties by Young [73] and by Samols et al. [74] for glucagon, and by Lernmark and Hellman [75] for an inhibitory islet substance later identified as somatostatin [76, 77]. Experimental evidence for both types of indirect islet cell interactions has been largely indirect and controversial [50]. The availability of pure islet cell preparations provided a model to assess more directly the actions of glucagon and of somatostatin on pancreatic B cells.

In binding studies with ${ }^{125}$ I-labelled glucagon, Van Schravendijk et al. [78] demonstrated that islet B cells possess high affinity receptors for glucagon from which labeled hormone was half-maximally displaced by $5 \cdot 10^{-9} \mathrm{~mol} / 1$ unlabeled hormone. Within a similar concentration range, glucagon also provoked a halfmaximal stimulation of cyclic AMP production in pure B cells (Fig.12, [69]). Besides confirming earlier reports on glucagon-induced adenylcyclase activation in islet cells $[79,80]$, our experiments discerned an exquisite glucagon sensitivity in the pancreatic B cells [69]. In previous work on isolated islets, the glucagon effects upon cyclic AMP formation have been noted for hormone concentrations of $10^{-7} \mathrm{~mol} / 1$ or higher [82-84]. Measurements in pure B cells demonstrated, however, that the cells are sensitive to 100 -fold lower concentrations (Fig. 12, [69]). The relative insensitivity of isolated islets to exogenous glucagon can be attributed to the presence of endogenously released glucagon, which can also account for the higher basal cyclic AMP levels in islet tissue as compared to isolated B cells [65, 69]. Compatible with this view is the finding that the cyclic AMP content of isolated $B$ cells can be restored to the levels measured in intact islets by the addition of islet A cells or of exogenous glucagon (Fig. 12, [69]). Interestingly, the variations in the cellular cyclic AMP levels were associated with parallel variations in the secretory responsiveness to glucose (Fig. 12, [65]). Thus, pure B cells were poorly responsive to glucose, while addition of dibutyryl cyclic AMP, of glucagon or of glucagon-containing A cells enhanced their secretory responsiveness up to the activities measured in intact islets [65]. A similar cyclic AMP dependency was also measured for the B-cell response to leucine, another nutrient secretagogue [65].

These observations led us to postulate that the insulin release process depends on a synergistic interaction between cyclic AMP and a nutrient-induced messenger (Fig. 13, [65, 85]). In isolated islets, locally released glucagon is thought to elevate the cyclic AMP levels in B cells, thus enabling them to generate a potent insulin release upon nutrient stimulation (Fig.13). A rise in plasma glucose is also rapidly followed by a marked discharge of pancreatic insulin. It seems therefore likely that, under normal in vivo conditions, islet B cells also benefit from stimulatory actions on their adenylcyclase system so that they readily release the appropriate amount of hormone (Fig. 13) Glucagon may participate in this in vivo regulation, since islet $B$ cells were found to be sensitive to concentrations (5. $\left.10^{-9} \mathrm{~mol} / \mathrm{l}\right)$ which are expected to be present in the afferent arterioles that enter the islets $[50,65,69]$; whether a proportion of $B$ cells is also exposed to higher concentrations of locally released glucagon is un- 


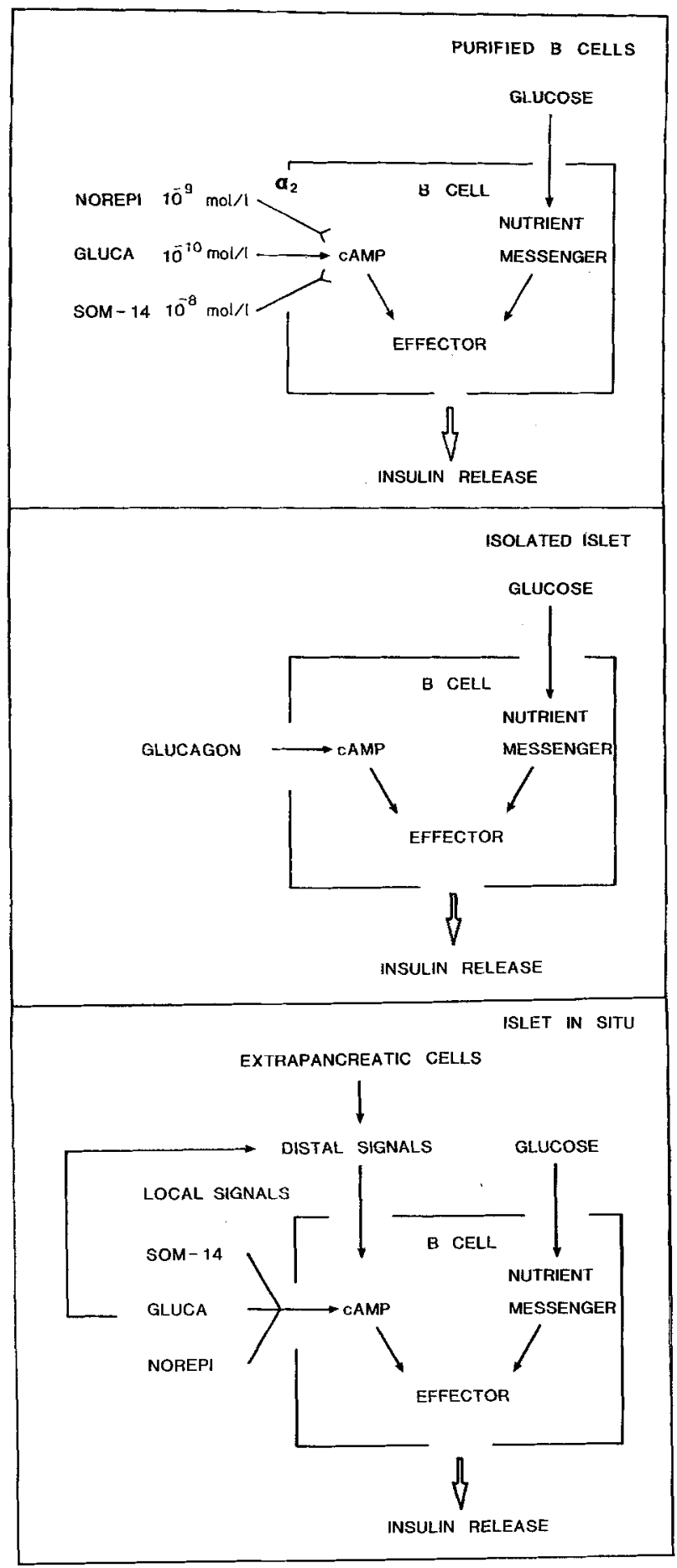

known, and cannot be predicted from the poor current insights into the properties of the islet interstitium [50].

Other islet cell products such as somatostatin-14 and norepinephrine may also participate in the in vivo regulation of the cyclic AMP-messenger system in B cells (Fig. 13). The inhibitory action of somatostatin-14 was, however, only detectable from $10^{-9} \mathrm{~mol} / 1$ on
Fig. 13. Model for the regulation of insulin release from pancreatic B cells. Studies on purified B cells (top) have demonstrated a synergistic control by nutrients and (neuro)hormones. The secretory responsiveness to glucose varies with the rate of cyclic AMP formation, and, hence, with the cellular interactions with (nor)epinephrine, glucagon and somatostatin-14. (Neuro)hormones which regulate cyclic AMP formation in islet B cells exert similar effects upon glucose-induced insulin release. In isolated islet preparations (middle), the addition of glucose alone is sufficient to cause an excessive release of insulin. Experimental evidence suggests that endogenously released glucagon generates sufficient hormone-induced signals conceivably cyclic AMP - to permit a marked secretory response to glucose. Normal islets in situ (bottom) are known to rapidly and massively release insulin in response to glucose. Their endocrine $B$ cells are therefore expected to be submitted to a sufficient (neuro)hormonal stimulation of the adenylcyclase system. Signals from local or distal origin are responsible for maintaining the synergistic control unit in a state of optimal glucose sensitivity

above $[65,69,86]$, which strongly suggests that if this pancreatic peptide exerts an in vivo action on $B$ cells it may only affect the cells which are located adjacent to the secretory pole of the islet D cells. Another subpopulation of $\mathrm{B}$ cells may be subject to an $\alpha_{2}$-adrenergic inhibition by norepinephrine. This neurotransmitter did indeed suppress cyclic AMP formation, and hence the secretory responsiveness to glucose, at concentrations which are expected to be present at neural endings [87].

The extent to which locally released substances set the glucose sensitivity of the islet B cells in vivo will vary with the activity of the producer cells as well as with their topographic relationship with the islet B cells. It will also depend on the nature and intra-islet concentration of signals which originate in distal sites (Fig.13). In establishing a varying and multifactorial. regulation of their adenylcyclase system, the $B$ cells seem capable of integrating multiple signals from different origins into an intracellular message which will determine the physiologically most appropriate sensitivity of the cells to nutrient stimuli. This form of sociologic organisation should provide a fine adjustment of the secretory function of pancreatic B cells to that of other pancreatic and extrapancreatic cells which are involved in glucose homeostasis (Fig. 13, Table 4). It is evident that similar adjustments can result from synergistic interactions with other messenger units such as the protein kinase $C$ regulatory system. Further experimentation on pure $B$ cells will have to assess the participation and relative importance of these routes. From a broader physiologic standpoint, it seems interesting to examine whether comparable coordinate pathways occur in other endocrine cell populations. A similar pattern has been noted in the regulation of pancreatic A cells, in which a synergistic interaction between cell specific nutrient and (neuro)hormonal signals was found to regulate the rate of glucagon release [86-88]. 


\section{Biosociology of B cells and diabetes}

\section{Pathogenesis}

The recognition of three levels of sociologic organisation within the pancreatic B-cell population, and their implications in biological processes which are critically important to the function of the endocrine pancreas, raises a number of questions with respect to the pathogenesis of diabetes. Can the disease, for example, result from a perturbation in the biosociology of the pancreatic B cells, or can a diabetogenic condition be counteracted by adaptations in the sociologic organisation of these cells? It also seems worthwhile to examine to which extent the present in vitro observations influence the interpretation of current diagnostic tests in diabetes, and how they may lead to more accurate and sensitive techniques to monitor pancreatic $B$ cells in vivo.

\section{Transplantation}

The notion that the function of islet B cells depends on their sociologic organisation stresses the need to define the optimal conditions for transplantation of islet tissue in diabetic recipients. First, the wish to reinstall functionally diverse B-cell subpopulations can be met by a precise selection of donor tissue. Second, the need to preserve the aggregated state of the transplanted cells will demand control on the nature and size of the graft, on its revascularisation and on its inflammatory reactions. Third, the functional impact of synergistic interactions with environmental signals will require an optimalisation of the cellular composition of the graft as well as of its implantation site.

That these reflections are not purely theoretical is illustrated in the model of intraportal islet transplantation. When isolated islets are isografted in the liver of streptozotocin-diabetic rats, they settle in the terminal radicles of the portal circulation, where they become revascularised and intimately associated with surrounding hepatocytes [89]. The overt signs of insulin deficiency disappear in the grafted animals, but their basal plasma glucose and insulin levels remain slightly higher than in age-matched controls, a feature which may be caused by the ectopic site of the insulin-releasing tissue [89]. The transplanted animals display normal glucose tolerance curves after oral loading but are slightly glucose-intolerant after an intravenous injection [90]. They develop, however, frank hyperglycaemia in conditions of stress, and this despite apparently sufficient insulin reserves in the liver $[89,90]$. The altered biosociology of the implanted B cells can explain several of these findings. In their intraportal site, the grafted cells will be intermittently exposed to levels of gastrointestinal hormones and nutrients which are consistently higher than in a pancreatic localisation. Furthermore, the juxtaposition of hepatocytes and the al-
Table 5. Survival of allografted islet tissue (RT1u) in streptozotocindiabetic rats (RT1n)

\begin{tabular}{lcccc}
\hline Graft & \multicolumn{4}{c}{ Weeks post-transplant } \\
\cline { 2 - 5 } & $<3$ & $3-10$ & $10-20$ & $>20$ \\
\hline Freshly isolated islets & $7 / 7$ & $0 / 7$ & $0 / 7$ & $0 / 7$ \\
Cultured isolated islets & $7 / 7$ & $1 / 7$ & $1 / 7$ & $0 / 7$ \\
$\begin{array}{l}\text { Islet cell aggregates after elimi- } \\
\text { nating Ia positive cells }\end{array}$ & $6 / 6$ & $3 / 6$ & $1 / 6$ & $0 / 6$ \\
$\begin{array}{l}\text { Purified islet cell aggregates af- } \\
\text { ter eliminating Ia positive cells }\end{array}$ & $10 / 10$ & $7 / 10$ & $7 / 10$ & $7 / 10$ \\
$\begin{array}{l}\text { Purified B-cell aggregates } \\
5 \text { weeks cyclosporin }\end{array}$ & $10 / 10$ & $10 / 10$ & $10 / 10$ & $10 / 10$ \\
\hline
\end{tabular}

Length of graft survival is determined by normal fasting plasma glucose levels and normal daily urine volumes. Data express number of recipients with surviving grafts on total number of recipients in each group

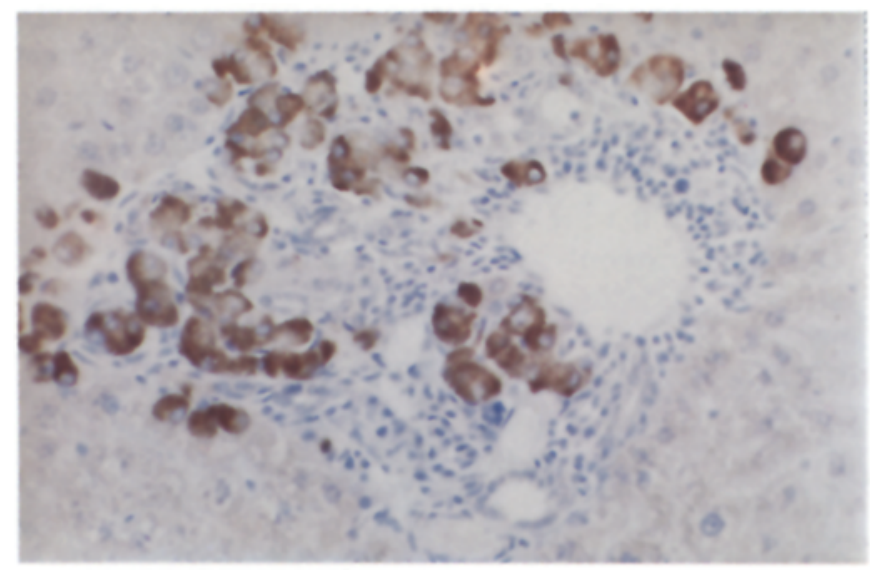

Fig. 14. Allograft of pure B-cell aggregates 20 weeks after intraportal injection in streptozotocin-diabetic rats. The recipient exhibited normal fasting blood glucose levels and a normal daily urine volume when killed. The donor cells are well granulated as indicated by the peroxidase-immunostaining for insulin

tered microanatomy of the grafted islets will create a local environment which differs markedly from that in the endocrine pancreas. In particular, the denervated state of the grafted cells can be considered as a functionally important alteration, since it results in a hypersensitivity of the transplanted cells to circulating catecholamines [90].

Along with the view that the biosociology of intraportally transplanted islets does not sufficiently meet the metabolic needs of the recipient, one could consider its optimalisation via adjustments in the cellular organisation of the graft and in its interactions with the new environment. Starting from purified islet cell preparations, aggregates of different cellular composition can be prepared [65] and tested for their ability to control glucose homeostasis after implantation in a particular site. Besides indicating the type of donor tissue which achieves an optimal metabolic control for a giv- 
en site, this model may also create the possibility to eliminate cells which induce the acute rejection of islet allografts $[91,92]$.

Since the biosociology of islet allografts will be primarily determined by their immune incompatibility, we examined first how the immunogenicity of the graft could be reduced by varying its cellular composition. The immunogenicity of freshly isolated mouse islets has been attributed to the presence of Ia-presenting cells, which constitute less than $5 \%$ of the total islet cell population [93]. It was therefore tested whether newly formed aggregates which are exclusively composed of Ia-negative islet cells can be transplanted across a major histocompatibility barrier. Our experiments were conducted in streptozotocin-diabetic rats, and used fluorescence-activated cell sorting to eliminate Ia-expressing cells from the donor cell preparation [52]. Aggregates composed of Ia-negative islet cells were rejected within 3 weeks after transplantation (Table 5, [94-96]). However, when the Ia-negative islet cells were submitted to autofluorescence - activated cell sorting to purify the endocrine islet cells $[15,21]$ - aggregates could be prepared which survived longer than 20 weeks in 7/10 allografted recipients (Table 5, [94-96]). Insulincontaining cells were readily recognised in the livers of long-term recipients of pure endocrine islet cell allografts (Fig.14). Several grafts presented mononuclear cell infiltrations at their periphery, suggesting that the purified endocrine islet cells express a moderate immunogenicity which may have been responsible for rejection in $3 / 10$ recipients. These mononuclear cell infiltrations were virtually absent when the recipients of pure endocrine grafts were treated for 5 weeks with a relatively low dose of cyclosporin [94-96]. In the drugtreated group, all animals maintained a functioning graft for over 20 weeks (Table 5, [94-96]). A temporary cyclosporin treatment was, on the other hand, unable to permit survival of unpurified islet tissue. Our studies with islet cell grafts of different cellular composition thus confirm that islet tissue represents a highly immunogenic allograft in rats $[97,98]$. They indicate, however, that in contrast to the mouse, the elimination of Ia-positive cells is not sufficient to produce a graft which is immunologically tolerated in rats. The purification of endocrine islet cells is, on the other hand, a much more successful method to prepare allografts which permanently survive in streptozotocin-diabetic rats. It should now be examined whether purification techniques also improve the survival of allografted B cells in recipients with autoimmune diabetes.

\section{Sociology of the 21st Minkowski Lecture}

Soon after discovering an antidiabetic activity in the pancreas, Minkowski examined whether the pancreatic organ could be used in the treatment of diabetes. Diabetic dogs received pancreatic tissue orally or subcu-

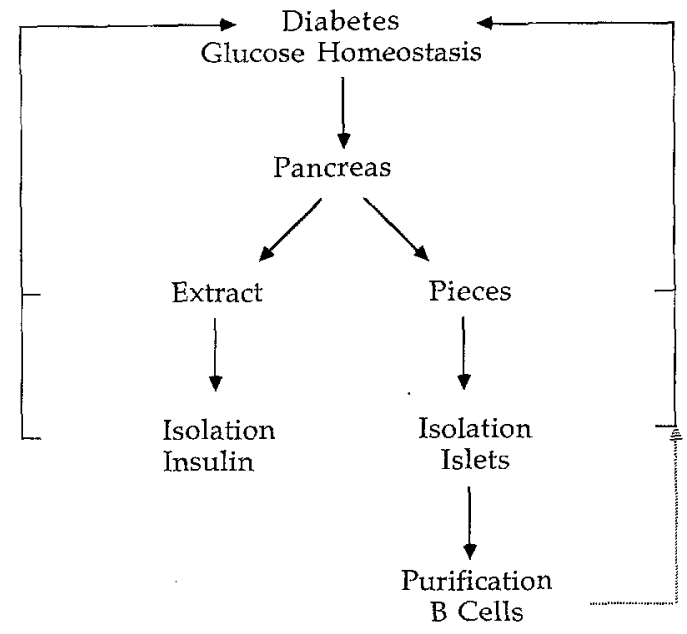

Fig. 15. The urge to purify and the need to feed back

taneously; others were injected with pancreatic extracts [2]. Although each of these initial attempts failed, they have indicated the routes along which the cure for diabetes could be sought. Today, almost one hundred years later, considerable progress has been achieved along each of these three routes. The advances are primarily the result of improvements in the form and in the purity of the administered preparations (Fig.15, [99-103]). Besides contributing to treatment, the techniques that were developed for the isolation and purification of insulin and of insulin-releasing tissue have provided successful tools for the study of diabetes (Fig. 15). The present work can be considered as a further extension of the project that was started by Minkowski and continued by numerous investigators (Fig. 15). It describes how insulin-releasing B cells can be purified from the mammalian pancreas, and illustrates the potential usefulness of pure islet cell preparations in several areas of diabetes research.

Being elected for this Minkowski lecture has been an honor for the nominee, but also for his early supervisors, Dr. W. Malaisse at the Université Libre de Bruxelles and Dr. D. Kipnis at Washington University in St.Louis, who deeply influenced his thoughts, views and experimentation. They are gratefully acknowledged for their generosity and advice. Dr. P.Lacy, Washington University, is thanked for his stimulating introduction to the field of islet transplantation, and Dr. W.Gepts, Vrije Universiteit Brussel, for his close collaboration and continuous support.

The work presented in this review has been collected after a long investment in a demanding project. It was therefore very dependent on the long-term support by the Belgian National Fund for Scientific Research, the Belgian Ministry of Scientific Policy and the Vrije Universiteit Brussel. It was achieved with the devoted technical assistance of M.Jacobs, N. Harnie, L. Heylen, J.C. Hannaert, S. Duys, G. Schoonjans, R. De Proft and B. Van Brabant and with the most reliable secretarial 
aid of A.M. Kiggen and N.Van Slycke. The experiments enjoyed an excellent collaboration of M. Van De Winkel, E.Maes, F.Gorus, C.Van Schravendijk, F. Schuit, P. In't Veld and M. Marichal. The availability of pure islet cells also led us into interesting collaborations with other institutions, thus enlarging the stimulating environment or "biosociology" of a project which is far from completed.

\section{References}

1. von Mering J, Minkowski O (1889) Diabetes mellitus nach Pankreasextirpation. Arch Exp Pathol Pharmakol 26:371-387

2. Minkowski O (1893) Untersuchungen über den Diabetes mellitus nach Exstirpation des Pankreas. Arch Exp Pathol Pharmakol 31: 85-103

3. Hedon E (1893) Sur la consommation du sucre chez le chien après l'éxtirpation du pancréas. Arch Physiol Norm Pathol 5: 154-163

4. Laguesse E (1893) Sur la formation de îlots de Langerhans dans le pancréas. C R Soc Biol 5: 819

5. Hellerström C (1964) A method for the microdissection of intact pancreatic islets of mammals. Acta Endocrinol 45: 122-132

6. Moskalewski S (1965) Isolation and culture of the islets of Langerhans of the guinea pig. Gen Comp Endocrinol 5: 342-353

7. Lacy PE, Kostianovsky MK (1967) Method for the isolation of intact islets of Langerhans from the rat pancreas. Diabetes 16: 35-39

8. Hellman B (1970) Methodological approaches to studies on the pancreatic islets. Diabetologia $6: 110-120$

9. Malaisse WJ (1973) Insulin secretion: multifactorial regulation for a single process of release. Diabetologia 9: 167-173

10. Orci L (1974) A portrait of the pancreatic B-cell. Diabetologia 10: $163-187$

11. Cerasi E (1975) Mechanisms of glucose stimulated insulin secretion in health and in diabetes: some re-evaluations and proposals. Diabetologia 11:1-13

12. Aschroft SJH (1980) Glucoreceptor mechanisms and the control of insulin release and biosynthesis. Diabetologia 18: 5-15

13. Taljedal IB (1981) On insulin secretion. Diabetologia 21:1-17

14. Howell SL (1984) The mechanism of insulin secretion. Diabetologia 26: 319-327

15. Pipeleers DG, in't Veld PA, Van De Winkel M, Maes E, Schuit FC, Gepts W (1985) A new in vitro model for the study of pancreatic A and B cells. Endocrinology 117: 806-816

16. Pipeleers DG, Pipeleers-Marical MA (1981) A method for the purification of single A, B and D cells and for the isolation of coupled cells from isolated rat islets. Diabetologia 20:654-663

17. Pipeleers DG, Pipeleers-Marichal MA (1979) A method for the preparation of A, B or D-cell enriched fractions from isolated islets of Langerhans. Excerpta Med Int Congr Ser 481: 186

18. Lindahl PE (1948) Principle of a counter-streaing centrifuge for the separation of paricles of different sizes. Nature 161 : 648-649

19. McEwen CR, Juhos ET, Stallard RW, Schnell JV, Siddiqui WA Geiman QM (1971) Centrifugal elutriation of the removal of leukocytes from malaria-infected monkey blood. J Parasit 57 $887-890$

20. Glick D, Von Redlich D, Juhos ET, McEwen CR (1971) Separation of mast cells by centrifugal elutriation. Exp Cell Res 65: 23-26

21. Van De Winkel M, Maes E, Pipeleers D (1982) Islet cell analysis and purification by light scatter and autofluorescence. Biochem Biophys Res Commun 107: 525-532
22. Pipeleers DG (1984) Islet cell purification. In: Lamer J, Pohl S (eds) Methods in diabetes research. Laboratory methods, part A. Wiley, New York, pp 185-211

23. Nielsen DA, Lernmark A, Berelowitz M, Bloom G, Steiner D (1982) Sorting of pancreatic islet cell subpopulations by light scattering using a fluorescence-activated cell sorter. Diabetes 31 : 299-306

24. Nielsen O, Larsen J, Christensen I, Lernmark A (1982) Flow sorting of mouse pancreatic B-cells by forward and orthogonal light scattering. Cytometry 3: 177-181

25. Rabinovitch A, Russell T, Shienvold F, Noel J, Files N, Patch Y, Ingram M (1982) Preparation of rat islet B-cell-enriched fractions by light-scatter flow cytometry. Diabetes 31: 939-943

26. Fletcher DJ, Grogan WM, Barras E, Weir GC (1983) Hormone release by islet $B$ cell-enriched and $A$ and $D$ cell-enriched populations prepared by flow cytometry. Endocrinology 113: 1791-1798

27. Van de Winkel M, Smets G, Gepts W, Pipeleers D (1982) Islet cell surface antibodies form insulin-dependent diabetics bind specifically to pancreatic B-cells. J Clin Invest 70: 41-49

28. Lernmark A, Freeman ZR, Hofmann C, Rubenstein AH, Steiner DF, Jackson RL, Winter RJ, Traisman HS (1978) Islet-cellsurface antibodies in juvenile diabetes mellitus. N Engl J Med 299: $375-380$

29. Alejandro R, Shienvold FL, Hajek SV, Pierce M, Paul R, Mintz DH (1984) A ganglioside antigen on the rat pancreatic Bcell surface identified by monoclonal antibody R2D6. J Clin Invest $74: 25-38$

30. Russell TR, Noel J, Files N, Ingram M, Rabinovitch A (1984) Purification of beta cells from rat islets by monoclonal antibody-fluorescence flow cytometry. Flow Cytometry 5:539-542

31. Van De Winkel M, Pipeleers D (1983) Autofluorescence-activated cell sorting of pancreatic islet cells: purification of insulincontaining B-cells according to glucose-induced changes in cellular redox state. Biochem Biophys Res Commun 114: 835-842

32. Pipeleers D, Van De Winkel M (1987) Separation of islet cells according to their functional characteristics. In: Pretlow TP, Pretlow TG (eds) Cell separation: methods and selected applications. Academic, New York London [in press]

33. Aubin JE (1979) Autofluorescence of viable cultured mammalian cells. J Histochem Cytochem 27:36-43

34. Benson RC, Meyer R, Zaruba M, McKhann G (1979) Cellular autofluorescence - is it due to flavins? J Histochem Cytochem 27: 44-48

35. Panten U, Ishida H (1975) Fluorescence of oxidized flavoproteins from perifused isolated pancreatic islets. Diabetologia 11: $569-573$

36. Malaisse WJ, Hutton JC, Kwazu S, Herchuelz A, valverde I, Sener A (1979) The stimulus-secretion coupling of glucose-induced insulin release. XXXV. The link between metabolic and cationic events. Diabetologia 16: 331-341

37. McDonald MJ (1981) Flavin content of intracellular compartments of pancreatic islets compared with acinar tissue and liver. Endocrinology 108: 1899-1902

38. Gorus F, Malaisse W, Pipeleers D (1984) Differences in glucose handling by pancreatic A- and B-cells. J Biol Chem 259: 1196-1200

39. Bencosme SA, Liepa E (1955) Regional differences of the pancreatic islets. Endocrinology 57: 588-596

40. Lazarus SS, Volk BW (1962) The pancreas in human and experimental diabetes. Grune and Stratton, New York, p 20

41. Hellman B (1967) Islet morphology and glucose metabolism in relation to the specific function of the pancreatic B cells. Excerpta Med Int Congr Ser 172: 92-109

42. Orci L (1982) Macro- and micro-domains in the endocrine pancreas. Diabetes 31: $538-565$

43. Orci L, Unger RH, Renold AE (1973) Structural coupling between pancreatic islet cell. Experientia 29: 1015-1018 
44. Michaels RL, Sheridan JD (1981) Islets of Langerhans: dye coupling among immunocytochemically distinct cell types. Science 214: 801-803

45. Meda P, Perrelet A, Orci L (1979) Increase of gap junctions between pancreatic B-cells during stimulation of insulin secretion. J Cell Biol 82: 441-448

46. Meda P, Denef JF, Perrelet A, Orci L (1980) Non random distribution of gap junctions between pancreatic B-cells. Am J Physiol 238: C114-C119

47. Maes E, Pipeleers D (1984) Effects of glucose and cyclic AMP upon reaggregation of single pancreatic B-cells. Endocrinology $114,2205-2209$

48. in't Veld P, Schuit F, Pipeleers D (1985) Gap junctions between pancreatic B-cells are modulated by cyclic AMP. Eur J Cell Biol 36: 269-276

49. in't Veld P, Pipeleers D, Gepts W (1986) Glucose alters the configuration of gap junctions between islet cells in the perfused rat pancreas. Am J Physiol 251: C191-C196

50. Pipeleers D (1984) Islet cell interactions with pancreatic B-cells. Experientia 40: 1114-1126

51. Orci L (1985) The insulin factory: a tour of the plant surroundings and a visit to the assembly line. Diabetologia 28: 528-546

52. Pipeleers DG, in't Veld PA, Pipeleers-Marichal M, Gepts W, Van De Winkel M (1987) The presence of pancreatic hormones in islet cells with MHC class II antigen expression. Diabetes 36 (in press)

53. Hume DA, Halpin D, Charlton H, Gordon S (1984) The mononuclear phagocyte system of the mouse defined by immunohistochemical localization of angigen F4/80: macrophages of endocrine organs. Proc Natl Acad Sci 81: 4174-4177

54. Shienvold FL, Alejandro R, Mintz DH (1986) Identification of Ia-bearing cells in rat, dog, pig and human islets of Langerhans. Transplantation 41: 364-372

55. Farr AG, Anderson SK (1985) In situ ultrastructural demonstration of cells bearing Ia Antigens in the murine pancreas. Diabetes 34: 987-990

56. Bottazzo GF, Dean BM, McNally JM, Mackay EH, Wift PGF, Gambel DR (1985) In situ characterization of autoimmune phenomena and expression of HLA molecules in the pancreas in diabetic insulitis. N Engl J Med 313: 353-360

57. Foulis AK, Farquharson MA (1986) Aberrant expression of HLA-DR antigens by insulin-containing B-cells in recent-onset type I diabetes mellitus. Diabetes 35: 1215-1224

58. Dean PM, Matthews EK (1968) Electrial activity in pancreatic islet cells. Nature 219: $389-390$

59. Pipeleers DG, Van De Winkel M (1986) Pancreatic B-cells possess defense mechanisms against cell-specific toxicity. Proc Natl Acad Sci USA 83: 5267-5271

60. Malaisse W (1982) Alloxan toxicity to the pancreatic B-cell: a new hypothesis. Biochem Pharmacol 31: 3527-3534

61. Hellerström C, Swenne I (1985) Growth pattern of pancreatic islets in animals. In: Volk BW, Arquilla E (ed) The diabetic pancreas. Plenum, New York, pp 53-79

62. Arndt-Jovin DJ, Jovin TM (1977) Analysis and sorting of living cells according to DNA content. J Histochem Cytochem 25: 585-589

63. Keeler KD, Thomas DB் (1980) Vital DNA staining and cell sorting by flow microfluorometry. J Cell Physiol 102: 175-181

64. Pipeleers DG, in't Veld P, Maes E, Van De Winkel M (1982) Glucose-induced insulin release depends on functional cooperation between islet cells. Proc Natl Acad Sci USA 79: $7322-7325$

65. Pipeleers DG, Schuit F, in't Veld P, Maes E, Hooghe-peters E, Van De Winkel M, Gepts W (1985) Interplay of nutrients and hormones in the regulation of insulin release. Endocrinology 117: 824-833

66. Halban PA, Wolheim CB, Blondel B, Meda P, Niesor EN, Mintz DH (1982) The possible importance of contact between pancreatic islet cells for the control of insulin release. Endocrinology 111: 86-94
67. Chertow BS, Branetsky NG, Sivitz WI, Meda P, Webb MD, Shih JC (1983) Cellular mechanisms of insulin release. Effects of retinoids on rat islet cell-to-cell adhesion, reaggregation and insulin release. Diabetes 32: 568-574

68. Hopcroft DW, Mason DR, Scott RS (1985) Structure-function relationships in pancreatic islets: support for intra-islet modulation of insulin secretion: Endocrinology 117: 3073-3080

69. Schuit F, Pipeleers D (1985) Regulation of adenosine 3',5'monophosphate levels in the pancreatic B-cell. Endocrinology 117: $834-840$

70. Pipeleers D, Pipeleers-Marichal M, Kipnis D (1976) Microtubule assembly and the intracellular transport of secretory granules in pancreatic islets. Science 191: 88-90

71. Meda P, Michaels RL, Halban PA, Orci L, Sheridan JD (1983) In vivo modulation of gap junctions and dye coupling between B-cells of the intact pancreatic islet. Diabetes 32: 858-868

72. Meda P, Perrelet A, Orci L (1984) Gap junctions and cell-to-cell coupling in endocrine glands. In: Modern Cell Biology, Volume 3, Alan R. Liss, New York, pp 131-196

73. Young FG (1963) Growth hormone and secretion of insulin. In: Cori DF, Foglia VB, Leloir LF, Ochoa S (eds) Perspectivess in biology. Elsevier, Amsterdam, pp 135-140

74. Samols E, Marri G, Marks V (1965) Promotion of insulin secretion by glucagon. Lancet $2: 415-416$

75. Hellman B, Lernmark A (1969) Inhibition of the in vitro secretion of insulin by an extract of pancreatic alfa 1 cells. Endocrinology 84: $1484-1487$

76. Dubois MP (1975) Presence of immunoreactive somatostatin in discrete cells of the endocrine pancreas. Proc Natl Acad Sci USA 70: $1340-1343$

77. Alberti KG, Christensen SE, Iversen J, Seyer-Hansen K, Christensen NJ, Hensen AP, Lundback K, Orskov H (1973) Inhibition of insulin secretion by somatostatin. Lancet 2:1299-1301

78. Van Schravendijk CF, Foriers A, Hooghe-Peters E, Rogiers V, De Meyts P, Sodoyez J, Pipeleers D (1985) Pancreatic hormone receptors on islet cells. Endocrinology 117: $841-848$

79. Goldfine ID, Roth J, Birnbaumer L (1972) Glucagon receptors in B-cells. Binding of 125-I glucagon and activation of adenylate cyclase. J Biol Chem 247: 1211-1218

80. Kuo WN, Hodgins DS, Kwo JF (1973) Adenylate cyclase in islets of Langerhans. Isolation of islets and regulation of adenylate cyclase activity by various hormones and agents. J Biol Chem 218: 2705-2711

81. Howell SL, Montague W (1973) Adenylate cyclase activity in isolated rat islets of Langerhans. Effects of agents which alter rate of insulin secretion. Bioch Biophys Acta 320: 44-52

82. Turtle JR, Kipnis DM (1967) An adrenergic receptor mechanism for the control of cyclic 3'5'adenosine monophosphate synthesis in tissues. Biochem Biophys Res Commun 38: 797-802

83. Kuo WN, Hodgins DS, Kno JF (1974) Regulation by various hormones and agents of adenosine $-3^{3}, 5^{\prime}$-monophosphate levels in islets of Langerhans of rats. Biochem Pharmacol 23: 1387-1391

84. Schauder P, Arends J, Schindler B, Ebert R, Frerichs H (1977) Permissive effects of glucose on the glucagon-induced accumulation of CAMP in isolated rat pancreatic islets. Diabetologia 13: $171-175$

85. Pipeleers D (1986) Purified islet cells in diabetes research. Horm Res 23: 225-234

86. Schuit FC, Pipeleers D (1986) Pancreatic A and B cells differ in their recognition of somatostatin. Diabetologia 29:592A

87. Schuit FC, Pipeleers DG (1986) Differences in adrenergic recognition by pancreatic $A$ and $B$ cells. Science $232: 875-877$

88. Pipeleers DG, Schuit F, Van Schravendijk C, Van De Winkel M (1985) Interplay of nutrients and hormones in the regulation of glucagon release. Endocrinology 117: 817-823

89. Pipeleers-Marichal M, Pipeleers D, Cutler J, Lacy P, Kipnis D (1976) Metabolic and morphologic studies in intraportal islet transplants. Diabetes 25: 1041-1051 
90. Pipeleers D, Pipeleers-Marichal M, Karl I, Kipnis D (1978) Secretory capability of islets transplanted intraportally in the diabetic rat. Diabetes $27: 817-824$

91. Lafferty KJ, Prowse SJ (1984) Theory and practice of immunoregulation by tissue treatment prior to transplantation. World J Surg 8: 187-197

92. Lacy PE, Davie JM (1984) Transplantation of pancreatic islets. Ann Rev Immunol 2: 183-198

93. Faustman D, Hauptfeld V, Lacy P, Davie J (1981) Prolongation of murine islet allograft survival by pretreatment of islets with antibody directed to Ia determinants. Proc Natl Acad Sci USA 78: $5156-5159$

94. Pipeleers D, Pipeleers-Marichal M, Van De Winkel M, Gepts W (1984) Use of purified B cells and cyclosporin-A in allografting diabetic rats. Diabetologia 27:320

95. Pipeleers-Marichal M, De Waele M, Van De Winkel M, Gepts W, Pipeleers D (1985) Islet cell selction for transplantation. Diabetes Res Clin Pract [Suppl I]: S 360

96. Pipeleers D, Pipeleers-Marichal M, Gepts W, Van De Winkel M (1987) Allotransplantation of purified islet cells. In: Brunetti P, Waldhäusl W (eds) Advanced models for the therapy of insulindependent diabetes. Raven Press, New York, pp 341-345

97. Rechard CR, Barker CF (1973) Transplantation of isolated pancreatic islets across strong and weak histocompatibility barriers. Transpl Proc V: 761-763
98. Gray DWR, Morris PJ (1984) Cyclosporine and pancreas transplantation. World J Surg 8: 230-235

99. Banting FG, Best CH (1922) The internal secretion of the pancreas. J Lab Clin Med VII: $256-271$

100. Saffran M, Kumar GS, Savariar C, Burnham JC, Williams F, Neckers DC (1986) A new approach to the oral administration of insulin and other peptide drugs. Science 233: 1081-1084

101. Albisser AM (1981) Artificial beta cells insulin delivery systems. In: Brownlee $M$ (ed) Handbook of diabetes mellitus, vol 5. Wiley, New York, pp 245-272

102. Kemp CB, Knight MJ, Scharp DN, Lacy PE, Ballinger WF (1973) Transplantation of isolated pancreatic islets into the portal vein of diabetic rats. Nature 244: 447-449

103. O'Shea G, Sun A (1986) Encapsulation of rat islets of Langerhans prolongs xenograft survival in diabetic mice. Diabetes 35 : 943-946

Professor D. Pipeleers

Department of Metabolism and Endocrinology

Vrije Universiteit Brussel

Laarbeeklaan 103

B-1090 Brussels

Belgium 